\title{
The Impact of Sectarian Conflict in Syria on Iran-Gulf Relations
}

\author{
Saleem A. Salih Al-Dulaimi ${ }^{1}$, Mohammad Kamal ${ }^{1}$ \& Dalal Mahmoud Elsayed ${ }^{1}$ \\ ${ }^{1}$ Faculty of Economy and Political Science, Cairo University, Cairo, Egypt \\ Correspondence: Saleem A. Salih Al-Dulaimi, PhD Candidate in Faculty of Economy and Political Science, \\ Cairo University, Cairo, Egypt. E-mail: salim66a@gmail.com
}

Received: April 10, 2017

doi:10.5539/ass.v13n7p92
Accepted: May 11, 2017 Online Published: June 23, 2017

URL: https://doi.org/10.5539/ass.v13n7p92

\begin{abstract}
Iran-Gulf relations are a confusing maze of complexities and contradictions. Iran's voracious aspirations have been manifest in more than one act and place. The 1979 Revolution created a pervasive atmosphere of anxiety and fear in the Gulf region of that revolution's ideological expansion into the Gulf states, especially those countries in which Shiites form important parts of their societies. In the Iran-Iraq war 1980, on the other hand, the Arab Gulf states supported Iraq against Iran as it was a proxy war to protect the Arab Gulf states, and Saddam Hussein, nevertheless, ended up occupying Kuwait in 1990. And then the Iranian-Gulf relations took a new turn at the time of both presidents Hashemi Rafsanjani and Mohammad Khatami, who adopted an open approach to the Gulf countries. However, those relations worsened when Ahmadinejad came to power as he started to export the revolutionary thought to the Gulf countries and extended the Iranian influence to Iraq after 2003, to Syria in the aftermath of the revolution that erupted in Syria in 2011 and to the Gulf Cooperation Council states, especially in Saudi Arabia, Kuwait and Bahrain. All this comes at the expense of the Gulf states, particularly Saudi Arabia, which is keen to maintain its influential role in the face of Iranian encroachment in Syria, through the support of the Syrian revolution, which seeks to overthrow Iran's ally in Damascus, Bashar al-Assad. Therefore, this study is trying to find an answer to this question: how has sectarian conflict in Syria impacted the Iranian-Gulf relations?
\end{abstract}

Keywords: Syria, Conflict, Iran, Sectarianism, Gulf States

\section{Introduction}

The US invasion of Iraq in 2003 threw the Gulf nations into total chaos with uncontrollable multi-form sectarian conflicts in Iraq and then Syria. Moreover, regional influential powers, such as Iran, interfered. Iran strongly engaged in Syria in favor of the regime of Bashar al-Assad in his war against the opposition of the majority of his people, and provided him with various international and regional types of power to help him, like forces from Hezbollah and other militias that are loyal to Iran, and other forces from the Gulf area such as organizations, associations and religious figures.

\section{Historical Context}

The advent of the Iranian revolution in 1979 was a major event in the region and Ayatollah Khomeini found an important entry point in Iraq to achieve the objectives of exporting the Iranian revolution (Nourbakhsh, 1996). The striking similarity between Syria and Iraq lies in their multi-ethnic, religious and sectarian populations. While Sunni Muslims and Christians are scattered across the country, the religious minorities of Muslims, Alawites, Druze, and Ismailis lived in particular geographical areas in Syria. 70\% of the 24 million Syrians are Muslims, 12\% of whom are Alawites (Van Dam, 2006). The Islamic Iranian revolution was essentially of Persian nationalist orientation (Al Ghurair, 2012). Iran, in the 1980s, introduced the "National Strategy" project which gives Iran a great aura of holiness, considering Iran as Umm al-Qura ("Mother of All Cities") (just like Mecca). The project attaches great importance to Iran's geopolitical position in foreign policy for regional expansion and hegemony (Bakir, 2015).

The sectarian difference between the two shores of the Gulf brought a semi-sustainable state of conflict between the two sides, and the creation of crises and wars of political, economic and security dimensions, using the various Islamic schools as an ideology of concealment the causes of that conflict. The geographical factor has played a role in defining Iran's policy towards the surrounding regions. One study has observed the number of times Iran has moved towards the surrounding territories, "Strategic Orientation", from 3200 BC to the present 
day. The study found that the Fertile Crescent came as the second most occupied region by the Persians (Iranians) and the southern region which includes the Gulf States came as the third most occupied region by the Persians. The Gulf States became the most affected parts by the policies of Iran's leaders after 1979 (Abdel-Hai, 2010).

Iran condemned the September 11 attacks in 2001 and criticized Islamic ideology that justifies these acts. Iran sought to promote the idea that Shiites and Iranians renounce terrorism and that the Gulf States and Wahhabis are the ones inciting and financing such terrorist acts (Alzoweiri, 2015). After the fall of the Taliban regime in Afghanistan and that of Saddam Hussein in Iraq, Iran worked on stabilizing the new situation in Iraq and unleashing its influence in there by reaching out to all groups, especially the Shiite extremist groups that had a historic opportunity to be invested in the interest of the sect and its people (Bar, 2009).

\section{Iranian Foreign Policy Foundations}

Iran's foreign policy is based on a set of foundations that have been governing Iran's policies in the region:

- Strengthening Iran's regional situation with other regional powers.

- Controlling and influencing water crossing points in the Gulf, the Arabian Sea and the Red Sea.

- Introducing itself as a leader of Shiites in the world and establishing relations with the Shiite communities surrounding Iran.

- $\quad$ Combating the US policy in the region (Bishara 2012).

Iran has its own regional project that does not change with the change of ruling elites or regional and international conditions, which is to remain the dominant regional power. This is all reflected in all Iranian proposals concerning the security of the Arab Gulf region. In 2006, Iran presented proposals regarding common security, security system and free-trade zones (Zarif, 2013).

The Iranian agrees that Iran's policy toward Iraq and Syria is a national security policy. They see that they have the right to possess nuclear energy. Iran has become a difficult and worrisome player, and once it feels dominant and able to subjugate neighbouring peoples, it moves on to implement its great project through subjugation or defection. Baghdad is being controlled by Iran now and cities deeply rooted in history such as Mosul, and Aleppo are being destroyed to eliminate that Arab demography and turn the Sunni Arab majority into a minority (Beshara, 2012).

\section{Iranian-Saudi Relations}

Iran and Saudi Arabia look upon themselves as political pivots in the Middle East to have control over countries in the region. Iran sees that political changes In the regions have given it the power to patronize some countries in the region. It used the Shiite doctrine as a tool to achieve its interests. Furthermore, it has been considered by the West as a state fighting terrorism in Iraq and Syria have all helped Iran to have such influence and dominance. As for Saudi Arabia, it finds itself a protector of the Two Holy Mosques, strategically threatened by pro-Iran forces in Iraq, Syria, Lebanon, and Yemen. Saudi Arabia also faces the challenge posed by Saudi Shiites, especially in the oil-rich regions in the eastern part of the kingdom. However, as it has the world's largest oil reserve and thanks to its huge financial potential, Saudi Arabia can buy its allies. Saudi Arabia's relationship with Iran has not stabilized since 1979, and the differences between the two countries are the result of a cold war over the roles to be played by both of them, the influence of Saudi Arabia and Iran are trying to exercise in the trouble hot spots in Lebanon, Syria, Iraq, Palestine, and Yemen (Atriesi, 2012).

Beside Sunni-Shiite dispute between Riyadh and Tehran, there is also a controversy over Iran's nuclear program, the clashes over oil and gas wells. The threat of Iran to close the Strait of Hormuz, and the conflict with Israel. Iranian President Hassan Rouhani is aware of the importance of his country's relations with Saudi Arabia. Rouhani said that he intended to "turn the rivalry between Iran and Saudi Arabia into a relationship based on mutual respect and cooperation in order to enhance security and restore stability in the region" (Institute For Defense Studies Analysis, 2013). The Iranian-Saudi relations began to deteriorate since the US war on Afghanistan because of Iran's desire to expand eastward and then in Iraq, where Iran's ambition to expand to the Mediterranean Sea. Thus, the competition between the two countries gradually began to take the form of a cold war after the political equation had changed and turned in Iran's favor (Shakdam, 2014).

\section{Interactions on the Security Side}

In October 1992, Hassan Al-Saffar, a Shiite cleric in Saudi Arabia and leader of the "Organization of the Islamic Revolution in the Arabian Peninsula", said he sympathized with Iran as a state and acknowledged the cooperation between his organization and Hezbollah. In 1991, Iran was able to contact Arab volunteers in Afghanistan after the Soviet Union had come out. Estimates pointed out that the thousands of Muslims who 
volunteered to fight in Afghanistan became active in the Islamic movements in their countries (US Department of State, 1994). Moreover, after the fall of the Taliban regime in 2001, most leaders of Al-Qaeda turned to Iran that forced some of them to fight US forces in Iraq after providing them with the tools to stay in contact with the leaders of jihad, such as Al-Zarqawi, leader of Al-Qaeda in Iraq (Idris, 2015). Later, Iran released some Al-Qaeda members in 2009. A letter to bin Laden said that the move may have been the result of the organization's operations against Iran, including the kidnapping of the deputy Iranian commercial attaché in Peshawar. "They do not want to show that they are negotiating or interacting with us" (Rassler, 2012).

In July 2016, the US Treasury Department imposed sanctions on several Al-Qaeda members living in Iran for supporting terrorist attacks across the region, including Syria. Although Iran and al Qaeda are at war in Syria and Yemen, they have developed a mutually beneficial relationship, at least concerning the presence of Al- Qaeda members operating from Iran. Iran virtually values the limited existence of Al- Qaeda on its territory as a form of power that can be used against the United States or against some neighboring countries such as Saudi Arabia, Pakistan or countries whose citizens are believed to be descended from Saudi Arabia and Pakistan (Byman, 2012).

Commenting on the killing of a Saudi diplomat in Karachi, Pakistan, in 2011, a Saudi official said that his country and the United States agreed that the Iranian Quds Force is involved in the incident and that Inter-Services Intelligence of Pakistan (ISI) had identified the murderer as a member of a Shiite group known as the Army of Muhammad, which has ties with the Iranian Quds Force (Alzoweiri, 2012). Furthermore, the US FPI investigations revealed that Iran was planning to kill the Saudi ambassador Adel Jubair in Washington in 2011.

In January 2016, the Saudi authorities executed the Shiite cleric Baqir Al-Nimr, an anti-government instigator in the predominantly Shiite eastern region of the kingdom. He was executed along with 46 other people who were convicted of being linked to Al-Qaeda. Al-Nimr was accused of being a "terrorist" threatening stability and security in Saudi Arabia. In Iran, on the other hand, protesters stormed the Saudi consulate in Mashhad and set fire to the kingdom's embassy in Tehran. As a result, the diplomatic relations between the two countries were broken off, and Iran's supreme leader Ali Khamenei warned that Saudi Arabia would face "divine retaliation" for killing Al-Nimr (BBC News, 2016).

The fall of the Iraqi regime in 2003 led to a new situation at the level of internal balances between the Iraqi political, ethnic, sectarian and regional parties and among Iraq's neighboring countries. The Shiites took power in Iraq and the Sunni reaction came in the form of violent resistance, and, consequently, the state disintegrated into a series of brutal doctrinal disputes, requiring the involvement of regional powers in Iraqi affairs, specifically Iran, Saudi Arabia, Turkey and Syria, for reasons related to their national security. From 2006 till the date of writing this paper Iraq has been torn by doctrinal and sectarian conflicts and proxy wars (Stansfield, 2008). Iran was able to get into the Iraqi political scene and despite the Iranian denial of that sectarian dimension in its foreign policy, the Gulf countries, led by Saudi Arabia, considered the sectarian factor one of the most important motives for Iran to emerge in the Iraqi scene (Kawtharani, 2013). In this regard, the commander of the Iranian Quds Force Qasem Soleimani - who leads the Iranian efforts to achieve hegemony in the region - is that the Islamic world for the Iranian authorities is divided between agents working for Iran and allies like those in Syria who constitute the so-called "Axis of Resistance", whereas Iran's Sunni neighboring countries, that are friends of the West, belong to the second camp (Fars News, 2014).

Iranians were not able to perform the annual pilgrimage rituals in Mecca in 2016 due to the death of hundreds of Iranian pilgrims in Mecca in 2015. This caused the deterioration of Saudi-Iranian relations, and, as a result, Iran took a decision to prevent its citizens from participating in the pilgrimage season. This was not a simple matter for the Iranian regime as Iran is the only country that publicly uses the pilgrimage season as a political tool to spread its revolutionary ideology abroad. Iran uses its Shiite religious networks associated with pilgrimage to serve its political agenda. The various pilgrimage missions in Iran provide sophisticated and effective methods to promote the Iranian version of political Islam and to strengthen Tehran's social and financial standing in the Islamic world (Khalaji, 2016). To Saudi Arabia, the crux of the matter is not the potential Iranian invasion, but Tehran constantly questions the political and regional legitimacy of the Saudi family. Iranian officials doubt Riyadh's tutelage over the most important Islamic sanctities. In September 2016, Supreme Leader Khamenei referred to the Sauds as the "devils." The response of the Grand Mufti of Saudi Arabia, Abdul Aziz Al-Sheikh, was to describe the Shiite majority in Iran as "deviant Zoroastrianists" that sanctifies fire and that they are "not Muslims" (Henderson, 2016).

In response, Saudi Arabia adopted a more assertive regional strategy to confront Iran. In Syria, Riyadh opposes 
any plan for a solution that involves the survival of the Assad regime, Iran's ally, while the latter believes it has a vital interest in maintaining the regime's structures to secure Hezbollah and defeat the Islamic State (IS). Tehran wants to point out to the West that it is the natural ally in the fight against groups such as al Qaeda and the Islamic State (IS). Iran also wants to discredit Riyadh and accuses it of being the source of this destructive ideology of such organizations. "Iran supports Assad not only in the framework of a Shiite alliance, but also because it dreams of reviving the ancient Persian Empire that stretched from the borders of China to the depth of the Middle East," says Henry Kissinger (Goldberg, 2016).

The policies of King Salman bin Abdul Aziz have been firmer and more militaristic regarding the regional conflict and centered on intervention in Yemen led by Saudi Arabia. There is a normative explanation that this adventurous approach stems from Riyadh's frustration at that American withdrawal from the Middle East, especially Washington's implicit complicity with Iran's aggressive behavior after the nuclear deal. Riyadh considered President Obama's reference to the Gulf States as a free beneficiary, a scorn. Indeed, Saudi Arabia has become too dependent on the United States in its strategic security, as part of the oil deal in return for security (Bahout, 2016).

Accordingly, the Saudi-Iranian conflict has become a geopolitical proxy war encapsulated in "Arab-Persian" ethnic conflicts and Shiite-Sunni sectarian disputes. Saudi Arabia has spent several billion dollars to counter Iran's influence in the region. Nevertheless, Syria, Lebanon, and Iraq are still in Iran's sphere of influence. It is only in Bahrain that Saudi Arabia has almost completely deterred Iran (Sadjadpour, 2016).

Because of the continuing tension between Iran and Saudi Arabia, trade relations have been limited; Saudi companies have been hesitant to invest in Iran, fearing that profits could not be made because of the hostility. Moreover, Saudi Foreign Minister Adel Al-Jubeir announced that Riyadh would cut "all trade relations with Iran after the execution of Baqir Al-Nimr. However, economists underestimate the impact of severing relations with Iran, because the volume of trade between the two countries does not exceed (500) million dollars (Sasapost, 2016). Tehran, on the other hand, decided on 7 January 2016, to ban the import of Saudi goods or any goods imported through the Kingdom (Al-Arabi 21-2016).

\section{Iran and the UAE}

Iran did not work to end the inherited problems with the UAE. UAE's dispute with Iran began in 1971 when the latter occupied islands of Greater and Lesser Tunb and Abu Musa. Despite the fact that they are small islands, they have great strategic and economic importance as they overlook the Strait of Hormuz through which about $40 \%$ of the world oil production passes daily. The UAE, as a Gulf state, supported Iraq in its war against Iran and also supported the United States in the war to get Iraq out from Kuwait in 1990. Therefore, there has always been that tension between the UAE and Iran (Katzman, 2015).

In 2012, Iran announced the establishment of a new province called "Persian Gulf" and made Abu Musa Island its capital. It also conducted dozens of military, naval and air maneuvers in the waters of the region. In return, the UAE rejected Iran's occupation of its islands. Nevertheless, the UAE has been careful not to contribute significantly to the escalation of international pressure on Iran, but has often sought to exploit such pressures to strengthen its trade and investment relations with Iran.

The United Arab Emirates is Iran's third largest market, as the UAE makes use of $80 \%$ of Iran-Gulf trade, while Tehran is the fourth largest trading partner in the UAE. Furthermore, the Iranian investments are the largest investments in Dubai. On the other hand, there are more than 450,000 Iranians living in the UAE whose population does not exceed 8 million people, nothing to say of the commercial and economic activities performed by Iranian companies in the UAE (Al Shihabi, 2012). The volume of trade in 2009 rose to $16 \%$ and reached $\$ 7$ billion, but it declined in 2011 due to the tightening of sanctions on Iran. The UAE was able to attract \$ 300 billion of Iranian capitals, which could be called the "Iranian businessmen lobby" (CIA, 2012). According to economic sources, the volume of trade exchange between Iran and the UAE amounted to \$15451 billion in 2015 (Sasapost, 2016).

Iran's attempts to export the revolution to the UAE are almost weak and limited, due to the presence of a large Iranian community in the UAE and Iran does not want to cause its subjects to experience any negative reaction in the UAE. However, the UAE leadership is aware of the magnitude of the terrorist threats that could be made by Iran or others, and, therefore, it has succeeded in confronting and aborting them before they occur. Moreover, the UAE has sought to enter into regional alliances in the GCC and conclude military cooperation agreements with the United States and NATO; it allowed the establishment of a French military base on its territory. The geopolitical role of Iran is the first and foremost concern for the UAE's foreign policy priorities, as reflected in its relationship with Iraq through its vision that Iraq became the Arab window of Iranian hegemony in the region 
after 2003, especially after the formation of a popular rally as Iran's arm in Iraq, and, for this reason, several Iraqi factions were included in their national list of terrorism issued in 2014 by the UAE (Decottignies, Cagaptay, 2016).

\section{Iran-Bahrain Relations}

The Iranian-Bahraini relationship is characterized by constant tension because of repeated Iranian demands to bring Bahrain back into Iranian territory. Iran views the presence of the US Fifth Fleet in Bahrain as one of the biggest problems and obstacles between the two countries. However, the ex-Iranian President Ahmadinejad visited Bahrain in November 2007 to reassure Manama that Iran was not aspiring to annex Bahrain. That was followed by a communiqué by Nateq Nouri in which he described Bahrain as "Iran's fourteenth province (Abu Amoud, 2009).

After the Islamic revolution, Iran has always been present in the Bahraini scene, especially by supporting the Shiites of Bahrain. Iran supported the Shiite opposition in Bahrain during the Iran-Iraq War and was involved in the attempt of coup d'état in 1981-1996. Moreover, the acts of espionage and sabotage by people from Bahrain, Iraq, and Hezbollah (US Department of State, 2012). Investigations made clear the attempts of the leaders of the Iranian Revolutionary Guards to overthrow the ruling Sunni monarchy and place an Iran-friendly Shiite-led government in Bahrain.

In the aftermath of the Arab Spring, Ali Velayati, Iranian foreign policy adviser to the supreme leader, said that "the people of Bahrain are not in a state of war with anyone...It is not permissible to treat the Shiites as second-class citizens in Bahrain", especially after Bahrain had used the forces of the Peninsula Shield on March 14, 2011, when the Iranian Foreign Minister said that "Tehran will not stand arms crossed watching the Shiites in Bahrain being killed" (Yusuf, Massaad, 2012). After Manama began countering the popular demonstrations in 2011, several Shiite militant groups organized themselves to confront the Bahraini government. In addition to the well-known Hezbollah organization in Bahrain, there are three other worrisome groups:

- Saraya Al-Ashtar: it issued its first statement in April 2013. Since then it has adopted 20 bombings against members of the security forces. It claimed responsibility for the March 3, 2011 bombing that resulted in the deaths of three policemen, including a UAE officer who was a member of the Peninsula Shield (US Department of State, 2015).

- Saraya al-Mukhtar: It started operations in September 2013 and adopted a number of attacks against Bahraini security forces, explosive device attacks.

- Popular Resistance Brigades: They also claimed responsibility for the attacks in Bahrain (Levitt, 2014).

Reports indicate that Iran provides the Shiite combat movements in Bahrain with support. For example, the Iranian Ghulam Shakouri, who was involved in an Iranian plot to assassinate the Saudi ambassador in Washington in 2011, is "a prominent officer in the Quds Force and has contributed to the organization of radical Shiite protesters in Bahrain." Shakouri and other Iranians met with the radical Shiite cleric Hasan Mushaima during a stopover in Beirut in February 2011,"when Mushaima was on his way back home to lead the protests in Bahrain" (Ignatius, 2011). On January 1, 2017, the storming of a prison in Bahrain resulted in the escape of 10 convicted Shiite prisoners with serious combat crimes. The well-planned operation and the killing of one of the guards is one of the many signs that Iran-backed cells have increased. On June 25, 2016, Iran's supreme leader Ali Khamenei described Bahrain's decision to revoke citizenship of Shiite leader Issa Qasim as a "crude folly." Qassem Soleimani, commander of the Quds Force, warned Bahrain against doing any harm to Sheikh Issa (Tasnim Iranian Agency,2016).

\section{Iranian-Kuwaiti Relations}

Kuwait maintained more liberal relations than those Saudi Arabia and Bahrain have had with Iran. The common interest in containing Iraq, as well as the Shiite community in Kuwait (estimated at $15-30 \%$ of the population), played a key role in keeping normal relations between Kuwait and Iran that became closer to friendship after 1991. However, Kuwait also views Iran as a potential threat due to that Iranian undeclared hostility toward Kuwait. In the spring of 2010, it was revealed that an Iranian cell was targeting the Kuwaiti energy facilities. Also, the Iraqi Hezbollah battalions made threats to attack the construction of the port of Mubarak al-Kabeer on Boubyan Island in July 2011 and the building of the Kuwaiti National Assembly in Kuwait City (US Department of State, 2011).

Emir of Kuwait visited Tehran in June 2015 and wished to resolve the Syrian crisis through peaceful means. Kuwait's policy is not fully neutral, but Kuwait has managed to play a political-diplomatic roles in the crises between the Gulf, especially Saudi Arabia, and Iran. Although Kuwait participated in the Arab alliance in Yemen 
and its stance was in line with Saudi Arabia's stance toward the execution of the Shiite opposition leader Al-Nimr, it did not agree with Saudi Arabia regarding the Iranian nuclear deal. The Kuwaiti role in resolving disputes was highlighted by the Kuwaiti mediation between Iran and Saudi Arabia, followed by the announcement of Kuwait's acceptance of negotiations with the Houthis in mid-April 2016 (Gulf Affairs, 2016). On January 25, 2017, the Kuwaiti Foreign Minister visited Iran and delivered a letter from the Emir of Kuwait to Iranian President Hassan Rouhani to calm tensions between the GCC and Iran and to ask Tehran to stop meddling in Arabs' internal affairs (Cafiero, 2017). As part of this orientation, Iranian President Hassan Rouhani visited Muscat and Kuwait on February 15, 2017, to restore Iran's strained relations with the Gulf (Middle East, 2017).

At the security level, in September 2015, the Attorney-General of Kuwait charged 25 Kuwaitis with one Iranian for committing acts that harmed the "unity and territorial integrity of Kuwait". Furthermore, it is Iran that started to provoke a diplomatic crisis with Kuwait after the Kuwaiti authorities had insisted on the trial of the members of Hezbollah cell in Kuwait (The Daily Mail, 2015).

\section{Iran-Qatar Relations}

Doha has been close to Tehran although some acts would sour Iran-Qatar relations from time to time. Doha was the first Gulf capital to break the boycott with Iran and called for Iran to take part in keeping security in the region. The former Emir Hamad al-Thani sought to play an important diplomatic role as a mediator in the region. However, and while pretending to be a powerful defender of resistance against Israel, Qatar hosted US military bases on its land. Qatar seeks to resolve conflicts in the Middle East, and in that capacity Qatar is seen by its neighbors as very close to Iran and its allies in the Middle East. In May 2008, Emir Hamad helped in the negotiations held in Doha between the Lebanese government and Hezbollah and Doha gave Hezbollah a one-third-plus-one share of Lebanese cabinet (Ottaway, 2009). Also, Qatar decided to invite Iran to attend the GCC summit in December 2007, without telling the GCC member states (Hammond, 2014).

The Arab Spring was a major factor in Qatar-Iran relations, especially with Iran's open support for Bashar al-Assad's regime and the Shiite opposition in Bahrain. Qatar, on the other hand, supports some of the revolutionary factions in Syria and the government in Manama as well. This rivalry over influence between Qatar and Iran has also extended to the Palestine issue, where the two countries are competing to support Hamas. But the question is: Would mediation by Qatar be accepted for the restoration of relations between the Gulf States and Iran? It is possible to settle any Gulf-Iranian differences through negotiation, and this was confirmed by the Qatari Emir during his dialogue with the Iranian president (The Daily Mail, 2016).

\section{Iran-Oman relations}

The special relations between Iran and Oman are based on the fact that the two countries have control over the Strait of Hormuz. After the establishment of the Islamic Republic, Sultanate of Oman sought to maintain good relations with Iran. However, the absence of a large Shiite bloc in the sultanate, in addition to the sectarian rapprochement between Shiite Iran and the Ibadid Sultanate, explains much of Oman's keenness to maintain good relations with Iran, unlike other Gulf States.

In August 2009 Sultan Qaboos visited Tehran after Ahmadinejad's re-election in what was considered an implicit endorsement of his re-election. In the following year, Tehran and Muscat signed a security agreement (Slackman, 2009). Many analysts point out that the US - Oman relations are more robust and diverse, while asserting that Oman maintains good relations with Iran to avoid any Iranian hostile action against it. Despite the pressure exerted by the GCC states, Oman has acted as a mediator in several regional crises, the most prominent of which was the nuclear negotiations between Iran and the West in 2013. US Secretary of State John Kerry praised the role of the sultanate in concluding the nuclear agreement. Furthermore, Muscat acted as a mediator between Tehran and Washington to release three American detainees arrested by Iran in 2009, and the United States, in turn, released an Iranian woman in 2012.

Oman, however, condemned the attacks on the Saudi embassy and consulate in Iran, referring to it as unacceptable behavior. However, Oman did not reduce diplomatic relations with Tehran. The Omani foreign minister visited Tehran to discuss the crisis instead. Muscat believes that political escalation, tension in the region and sectarian strife are very unfortunate and may affect the national interests of the sultanate in the region.

In 2015, the sultanate made a great effort to promote dialogue between the conflicting parties in both Syria and Yemen. However, Saudi Arabia and a number of its allies have cut or reduced their relations with Iran. This crisis is a stumbling block to the fragile initiatives to resolve the crisis in Yemen and Syria. Oman faces serious economic problems due to the lower oil prices. Therefore, importing natural gas from Iran is an important 
economic demand for Oman (Postnet, 2016). Oman and Kuwait have played pivotal mediatory roles in both the Syrian and Yemeni crises. According to some sources, some secret dialogues and negotiations were held in Muscat concerning Syria. Kuwait and Oman have also acted as mediators in the Saudi-Iranian crisis. Moreover, Oman believes that it is necessary to adopt peaceful solutions to the Yemeni crisis (Al-Quds Al-Arabi, 2015).

\section{The Sunni-Shiite Conflict}

The existence of Persian Iran with a sectarian Shiite orientation, next to an Arab bloc with a Sunni majority, gets Iran to strongly reject any Arab political bloc, considering it a threat to its security and interests. Tehran does not like dealing with the GCC or other Arab regional organizations (Abd al-Mumin, 2012). Tehran expressed its unwillingness to receive the Tripartite Commission from Saudi Arabia, Oman and Qatar to open dialogue about finding a solution to the issue of the UAE islands. However, Tehran was ready to receive the European Troika, which included the Foreign Ministers of France, Britain and Germany, to negotiate for its nuclear file. Iran does not want to deal with Gulf States through the GCC (Nasser, 2012).

As a result, the Gulf States, found the Syrian revolution in March 2011 an opportunity to influence the balance of power after the American withdrawal from Iraq. After the Sunni Gulf States, along with Turkey, had failed to persuade Assad in 2011 to deal positively with the demands of the Sunni majority in his country, they decided to keep Syria away from the Arab League and to take strict diplomatic measures against the Assad regime (Holliday, 2011).

For purely geopolitical reasons, Riyadh saw that Iran's expanding influence in Iraq and strong presence in Syria would pose a threat to the GCC member states. Also, the rise of Iranian influence in Yemen, embodied in the Huthis, and Tehran's constant attempts to intervene in the internal affairs of the Gulf States made Riyadh think twice and seize the opportunity to correct the balance of power in their favor by bringing Iran's most important ally in the region down and cutting that link between Hezbollah in Lebanon and Iran. Riyadh, Turkey and Qatar also supported the use of military force to overthrow the Assad regime, either by arming the opposition, or through regional or international military intervention (Qablan, 2015).

Riyadh, Doha and, to some extent, the UAE desired to eliminate the Iranian influence in Syria by supporting the Syrian revolution against Bashar al-Assad's regime. Saudi Arabia supports the opposition delegation negotiating with the Assad regime in Geneva and Astana in 2017. Riyadh also hopes that Russia's presence in Syria will replace Tehran's influence. The same is true about the Saudi policy towards Lebanon; Riyadh supported Sunni Prime Minister Saad Hariri and encouraged him to firmly stand up to Hezbollah. On the other hand, the continued existence of fragile government in Lebanon and the growing political power of Hezbollah, Tehran's ally, have all caused Saudi Arabia to cut all its aids to the Lebanese army and directly threaten to reduce other forms of support for the state and the Lebanese economy (Bahout, 2016).

\section{Establishment of Naval Bases}

Iran works on building two maritime zones and three naval bases on the shores of the Sea of Oman (Kam, 2016). If, ultimately, Iran succeeds in establishing naval bases on the shores of Syria and Yemen, this will have negative repercussions for regional and global powers such as Israel, Saudi Arabia, Egypt, Turkey and the United States. It is unclear whether Iran is considering establishing a permanent base in Syria. Furthermore, Iran's having permanent military presence in the Mediterranean would create a threat and a kind of deterrence against the Arabs and Israel. All that has made Saudi Arabia and the UAE build naval bases in Djibouti and Eritrea to give them the advantage of controlling the Red Sea region (Guzansky, 2017).

\section{Reflection of Sectarian Conflict on Relations}

The broader feature of the Gulf-backed Syrian opposition is its Sunni identity as most of the insurgents in Syria are Sunni Arabs." This religious homogeneity is nonetheless not enough to provide the armed opposition with that military cohesion and the unified political identity desperately needed (Balanche, 2016).

The Iranian role is clear and influential in the continuation of the conflict in Syria and in rescuing the Assad regime from falling. Iran has used Shiite fighters from several countries to strengthen and support the Syrian regime and to prevent it from falling as one of the most important states that constitutes the Mideast Shia crescent. Iran has also signed arms and energy agreements with Russia, China, India and other countries in order to strengthen its position against foreign intervention and succeeded in preventing the Security Council from issuing a resolution authorizing the use of international forces in Syria as the United States had already done in Libya. Moreover, the military relations between Syria and Iran have improved because of the blockade and those sanctions imposed by the West against the two countries (Blanchard, et al., 2015). 


\section{The Gulf Fears of Nuclear Agreement}

The most assertive approach followed by Saudi Arabia and the UAE came in response to the diplomatic initiatives taken by the Obama Administration towards Tehran within the framework of the nuclear agreement. According to an interview made by the New Yorker magazine in January 2014 with the then American President Obama, he envisioned a "new geopolitical equilibrium" in the Gulf region. Furthermore, signing the Joint Action Plan in July 2015 underscored the Gulf's fears of the US administration's realignment policy in the region and widened the gap between the United States and its allies with Washington's apparently embracing Tehran - in Iraq and Syria - as a potential force for stability in the region (Schenker, 2016).

The Gulf countries' main concern stems from their belief that Iran is seeking regional hegemony by using terrorism, and, therefore, the nuclear deal has made things worse as the lifting of sanctions has removed Iran's isolation as a rogue state and given it more revenues. The nuclear agreement has fueled Iran's ambition to become a dominant power in the region (Riede, 2016).

Henry Kissinger says: "My foreign policy theory has always been to try to link legitimacy with force, and the crisis created by Iran was to link nuclear capabilities with imperialist ambitions and foreign policies in support of armed groups in Syria, Lebanon and Yemen. The lifting of sanctions against Iran should have been linked to reducing uranium enrichment in the Iranian nuclear reactors and ending Iran's support for armed entities such as Hezbollah. (Goldberg, 2016).

\section{The Proxy War}

In parallel with Tehran's approach to "exporting the revolution", Ayatollah Ali Khamenei and the Islamic Revolutionary Guard Corps (IRGC) have developed tactics for an asymmetrical war aimed at building Iranian influence through sectarian and political alliances. Iran often considers itself the guardian of the wider Shiite community. Iran has set up networks of Shiite militias: Hezbollah in Lebanon, Houthis in Yemen, and dozens of other militias in Iraq. Moreover, Iran has expanded its influence among the Alawites in Syria and dominated the Shiite religious establishment and financial networks throughout the Middle East. Iran has also deepened its ties with Sunni Arab warring factions in the Middle East to strengthen its regional standing. To that end, Tehran has developed strong relations with Hamas and the Islamic Jihad in Gaza. In fact, Iran does not care about Muslims, even the Shiites; Iran has allied itself with Christian Armenia against pro-American Shiite-majority Azerbaijan and with the Afghan Taliban against the Afghan government. Eventually, it is the imperial ambition that drives Iranian foreign policy (Cagaptay, Jeffrey, Khalaji, 2015).

Acts of violence, sectarian speeches - along with fixed salaries - have allowed Iran to successfully recruit thousands of Shiite fighters over the past years. Thus, these factors are likely to be once again the main stimulus for mobilization. The large investments Iran uses in recruiting and training these agents strongly suggest that they intend to maintain their presence abroad (Ghaddar, 2016).

Riyadh accuses its regional enemy, Tehran, of supporting the Houthis in Yemen with weapons, training and funding. For its part, Iran accuses Saudi Arabia and the Arab Alliance of killing civilians in Yemen, describing its war in Yemen as "aggression". This tension is reflected in the statements made by the foreign ministers of the Gulf States and Iran. The Iranian Foreign Ministry attacked the UAE and Saudi Arabia in response to the accusations made by the foreign ministers of the two gulf countries against Iran of Tehran's supporting the Houthis (Mohammad, 2016).

The accusations came from the United Arab Emirates and Saudi Arabia after the Arab alliance had intercepted a rocket fired by the Houthis toward Mecca (holy city). Saudi Foreign Minister Adel al-Jubeir said that "the Iran-backed Houthis have not respected the sacred land of the country". On the other hand, on October 1, 2016, a UAE aid vessel was attacked by the Houthis. Iran then said that "attacking the UAE vessel occurred to defend Yemen's sovereignty" (Al-Arabi 21, 2016).

After the lifting of sanctions, Iran began to increase its oil production, and with the decline in oil prices, which is pressing those countries to diversify its economy, it is doubtful that the cohesion of the GCC countries would hold. The shift in local economic standards is having a geopolitical impact on the region. GCC states are seeking to find reliable allies to help them face regional challenges and stabilize oil prices as well. There is a feeling that the United States no longer gives priority to its relations with the Gulf states, including its privileged relations with Saudi Arabia. Gulf Statea and Saudi Arabia responded to these changes by adopting stronger and more independent foreign policies, as well as deepening their internal relations (Ghafar, 2016).

\section{Conclusion}

The lifting of sanctions on Iran strengthened its desire and ability to finance its regional influence, in addition to 
the gains and victories achieved by its forces and supporters in Iraq and Syria, against the opposition organizations. Some of those opposition organizations are already classified as terrorist organizations. Moreover, Iran receives political and military support from Russia and China. Also, the West is open with Iran at the political and economic levels now. All that makes it difficult to have a change in the region. What can be clearly seen in the region now is a change in the balance of power. The United States is turning to Iran as a key player in the Middle East equation now. Another important issue that has raised the concerns of the Gulf states is that the Iranian Revolutionary Guards in 2015- 2017 conducted tests to develop its missile programs. The most pessimistic predictions are that the region is on the verge of a long war, similar to that between Catholic and Protestant states, for control and influence in the $17^{\text {th }}$ century. A proxy war, in which the winner gains everything on a sectarian basis. Therefore, the Gulf states are seeking to secure a military victory by allying with Turkey, France and Britain, through a series of military and security agreements and providing support for the Syrian opposition fighters or for those negotiating with the Russians and the Iranians.

\section{References}

Abdel Ghafar, A. (2016, November). GCC: Rethinking Alliances, Newsweek. November 2, 2016. Retrieved from http://newsweekme.com/gcc-rethinking-alliances/

Abdelmo’men, M. S. (2012). The Third Republic in Iran. Cairo: Egyptian General Book Organization. P.227.

Abdul Hai, W. (2010). Iran: Future of Regional Position 2020. Algeria: Center for Applied Studies. PP. 16-40.

Abu Amoud, M. S. (2009). Iran and the Arab Gulf States, and Influential Relations. Al-Siyassa Al-Dawliya Journal, 176, 227.

Al-Ghurair, M. Arab-Iranian Relations in the Arabs and Iran. Review in History and Politics A. \& Zuwair, M. (eds.), The Arabs and Iran: A Review of History and Politics, Beirut, Dar Al-Arab Al-Arabiya Press. P.167.

Al-Quds Al-Arabi, Issue No. 8199, August 18, 2015.

Al-Sharq Al-Awsat newspaper, Issue No. 12970, June 2, 2014.

Al-Sharq Al-Awsat newspaper, Issue No. 13959, February 15, 2017.

Al-Shehabi, O. (2012). Uprootedness, Real Estate Projects, and the Exacerbation of the Demographic Imbalance in the GCC, Beirut: Center for Arab Unity Studies.p.32.

Al-Zuwairi, M. (2015). Iran and the Houthis: Making Chaos in Yemen. Journal of Studies, 1, 71.

Al-Zuwairi, M. (2012, May). Al-Jazeera. Iran-Saudi Relations in Light of Hot Files in the Region. Retrieved from http://studies.aljazeera.net /ar/reports/2012/05/20125983013255262.html\# anc4

Atrissi, T. (2012). The Arabs and Iran: Common Interests and Unstable Relationships. In Bishara, A. \& Zuwair, M. (Eds.), The Arabs and Iran: A Review of History and Politics, Op. Cit.p.110.

Bakir, A. H. (1995). Iran and the Middle East Competition. In Al-Nafisi, A. \& Al-Tantwi, A. (Eds.), The Iranian Project in the Arab and Islamic Region, Egypt: Dar Al Bashir for Culture and Sciences.p.p95-96.

Bar, S. (2009). Iranian Terrorist Policy and Export of Revolution, Working Paper on The Balance of Israel's National Security and Resilience, The Annual Herzliya Conference, February, 2-4. 2009. (pp.17-19).

BBC, "Iran: Saudis Face" Divine Revenge for Executing Al-Nimr", BBC News, January 1, 2016. Retrieved from http://www.bbc.com/news/world-middle-east-35216694

Bishara, A. The Arabs and Iran: General Observations, Op.Cit.P.10-11.

Byman, D. (2012). Unlikely Alliance: Iran’s Secretive Relationship with Al-Qaeda IHS Defense, Risk and Security Consulting. PP. 26-33.

Cafiero, G. (2017). Can Kuwait Facilitate a Thaw in Saudi-Iranian Relations?, lobelog, Februar. Retrieved from https://lobelog.com/can-kuwait-facilitate-a-thaw-in-saudi-iranian-relations/

Cagaptay, S.Jeffrey, J. F., \& Khalaji, M. (2015, April 26). Iran Won't Give Up on Its Revolution. The New York Times. Retrieved from http://www.nytimes.com/2015/04/27/opinion/iran-wont-give-up-on-its-revolution. html?_r=0

Carnegie Endownment for Intrenational Peace (2016). Saudi Arabia's Changing International Role. Retrieved from http://carnegie-mec.org/2016/04/18/ar-63414/ixg3

Central Intelligence Agency (2012). The World Factbook (Iran). Retrieved from https://www.cia.gov/libraw/publications/the-world-factbook/geos/ir.html 
Congressional Research Service. (2017). Nikitin, M., Blanchardi, C., \& Humud, C. (2017), Armed Conflict in Syria: Overview and U.S. Response. Retrieved from https://fas.org/sgp/crs/mideast/RL33487.pdf

Congressional Research Service. (2017). Katzman, K. The United Arab Emirates: Issues for U.S. Policy. Retrieved from https://fas.org/sgp/crs/mideast/RS21852.pdf

Dam, N. V. (2006). The Struggle for Power in Syria, Sectarianism, Regionalism and Tribalismin Politics. Retrieved from files/ar/Nikolaos\%20Van\%20Dam_Struggle.for.Power.in.Syriap pdf

Fars News Agency (2014, February 13). No Country but Iran Is Capable of Leading the Muslim World. Retrieved from http://www.farsnews.com/newstext.php?nn=13921124000724

Goldberg, J. (2016). The Lessons of Henry Kissinger. The Atlantic. Retrieved from http://www.theatlantic.com/magazine/archive/2016/12/the-lessons-of-henry-kissinger/505868/

Guzansky, Y. (2017). Iran's Growing Naval Ambitions, Foreign Affairs. https://www.foreig affairs.com/articles/iran/2017-01-01/irans-growing-naval-ambitions

Hammond, A. (2014) Saudi Arabia and Iran: Rouhani fades as Riyadh focuses on containment. In Post-Nuclear: The Future for Iran in its Neighborhood" (London, European Council on Foreign Relations), pp.13- 14.

Holliday, J. (2011). The Struggle for Syria in 2011: an Operational and Regional Analysis. Middle East Security Report 2, Institute for the Study of War, pp. 23-24.

Idris, A. I. "The Consequences of the Iraq Invasion on the Strategic Options of the Gulf " in "Ten Years That Shook the World, Op.Cit.p.415.

Ignatius, D. (2011. October 13). Intelligence Links Iran to Saudi Diplomat's Murder, The Washington Post. Retrieved from https://www.washingtonpost.com/blogs/post-partisan/post/intelligence-links-iran-to-saudidiplomats-murder/2011/10/13/gIQAFzCPiL_blog.html?utm_term=.1146bab774f6

Institute For Defences Studies Analyses (2013). Iran under Hassan Rohani: Imperatives for the region and India. Retrieved from http://www.idsa.in/issuebrief/IranunderHassanRohani_RoyAgarwalKumarRizvi_190713

Iran Escalates and the Gulf States Presses by the economic Files (2016, January 8). Retrieved from https//arabi 21.com/story/880900.

Kam, E. (2016). Iran: Naval Bases in Syria and in Yemen? Tel Aviv: The Institute for National Security Studies, INSS Insight No. 879. P.P 1-3.

Kawtharani, W. "the Arabs and Iran between Memory and History". In Bishara, A. \& Zuwair, M. (Eds.), The Arabs and Iran: A Review of History and Politics, Op.Cit.p.52.

Mohammed, S. (2013). The Iranian Policy towards the GCC Countries 1997-2012, (unpublished doctoral dissertation). Institute of Arab Resarch Studies, Cairo, Egypt. p.123.

Nourbakhsh, M. (1996), Religion, Politics, and Ideological Trends in Contemporary Iran. In Iran and the Gulf: The Quest for Stability. The Quest for Stability, in Jamal Al Suwaidi, Abu Dhabi, Emirates Center for Strategic Studies and Research.p.35.

Ottaway, M. (2009, November). Iran: the United States, and the Gulf: The Elusive Regional Policy. Carnegie Endowmen for International Peace, No.105.P13-14.

Post Policy Site. (2016, February). Retrieved From http://www.sasapost.com/gulf-investment/

Qablan, M. (2015). The Implications of Iraq Occupation on the Regional Balance of Power in the Gulf. In A Group of Author, Ten Years That Shook the World, Beirut, Arab Center for Research and Policy Studies. pp. 396-397.

Rassler, D. et al. (2012). Letters From Abbottabad: Bin Ladin Sidelined? Combating Terrorism. Retrieved from https://www.ctc.usma.edu/posts/letters-from-abbottabad-bin-ladin-sidelined

Reuters. (2010). Doherty, R.E., Lewis, B. \& Urquhart, M., Factbox: Qatar, Iran Share World's Biggest Gasfield. Retrieved from http://www.reuters.com/article/us-northfield-qatar-idUSTRE 66P1VV20100726

Sadjadpour, K. (2016). What Are The Prospects of Rapprochement Between Saudi Arabia And Iran?. In "Saudi Arabia’s Changing International Role. Retrieved from http://carnegie-mec.org/2016/04/18/ar-63414/ixg3

Schenker, D. (2016). The Shift in Saudi Foreign Policy 2016. Washington: Institute for Near East Policy.p.1.

Shakdam, C. (2014). The Disintegration of the Saudi Empire and the New Iranian Axis. New Eastern Outlook. Retrieved from http://journal-neo.org/2014/11/12/the-disintegration-of-the-saudi-empire 
Slackman. M. (2009, May 16). Oman Navigates Risky Strait Between Iran and Arab Nations. New York Times. Retrieved from http://www.nytimes.com/2009/05/16/world/middleeast/16oman.html

Stansfield, G. Security of the Arabian Gulf after the Invasion of Iraq, In Iran and the Gulf: The Quest for Stability. The Quest for Stability, in Jamal Al Suwaidi Op.Cit.p.135.

Tasnim Iranian Agency. (2016). International Condemnations for Withdrawing the Citizenship from Ayatollah Cheikh Isaa Qassem. Retrieved from http://www.tasnimnews.com/ar/news/2016/06/21/1110642

The Brookings Institution. (2016). What the Iran Deal Has Meant for Saudi Arabia and Regional Tensions. Retrieved

from http://www.brookings.edu/blogs/markaz/posts/2016/07/13-iran-deal-saudi-arabia-tensions-riedel

The Daily Mail. (2015). Kuwait Seizes Arms, Holds Suspects in Militant Plot -Local Media. Retrieved from http://www.dailymail.co.uk/wires/reuters/article-3197029/Kuwait-seizes-arms-holds-suspects-militant-plot-l ocal-media.html

The Washington Institute. (2014). Levit, M. Iran and Bahrain: Crying Wolf, or Wolf at the Door? Retrieved from http://www.washingtoninstitute.org/policy-analysis/view/iran-and-bahrain-crying-wolf-or-wolf-at-the-door

The Washington Institute. (2016). Henderson, S., Holy War of Words: Growing Saudi-Iranian Tensions. Retrieved from http://www.washingtoninstitute.org/policy-analysis/view/holy-war-of-words-growing-saudiiranian-tensions

The Washington Institute. (2016). Iran May Be Using Iraq and Syria as a Bridge to Lebanon. Retrieved from http://www.washingtoninstitute.org/policy-analysis/view/iran-may-be-using-iraq-and-syria-as-a-bridge-to-le banon

The Washington Institute. (2016). Khalaji, M, Iran's Ideological Exploitation of the Hajj. Retrieved from http://www.washingtoninstitute.org/policy-analysis/view/irans-ideological-exploitation-of-the-hajj

The Washington Institute. (2016). Status of the Syrian Rebellion: Numbers, Ideologies, and Prospects. Retrieved from http://www.washingtoninstitute.org/policy-analysis/view/iran-may-be-using-iraq-and-syria-as-a-brid ge-to-lebanon

U.S Department of State. (1994). Country Reports: Middle East and North Africa Overview in Country (Reports on Terrorism 1993. Retrieved from https://www.treasury.gov/resource-center/sanctions/Documents/tar1994. pdf

US Department of State (2012). Country Reports: Middle East and North Africa Overview in Country (Reports on Terrorism 2011. Retrieved from http://www.state.gov/j/ct/rls/crt/2011/195544.htm

US. Department of State (2015). Country Reports on Terrorism. Retrieved from https://www.state.gov/j/ct/rls/crt/2014/

Youssef, A., \& Massad, N. (2012). The State of the Arab Nation 2011-2012: The Challenges of Change and its Prospects, Beirut: Center for Arab Unity Studies. PP.86-88

Zarif, M. A. (2013.November 21). Our Neighbors Our Priority. Al-Sharq AL-Awsat newspaper.

\section{Copyrights}

Copyright for this article is retained by the author(s), with first publication rights granted to the journal.

This is an open-access article distributed under the terms and conditions of the Creative Commons Attribution license (http://creativecommons.org/licenses/by/4.0/). 